\title{
Impact of Financial Performance on Green Banking Disclosure: Evidence from the Listed Banking Companies in Bangladesh
}

\author{
Md. Kazimul Hoque, Mofijul Hoq Masum*, Md Abdullah Babu \\ School of Business and Economics, United international University, Bangladesh \\ Received November 5, 2021; Revised December 28, 2021; Accepted January 16, 2022
}

\section{Cite This Paper in the following Citation Styles}

(a): [1] Md. Kazimul Hoque, Mofijul Hoq Masum, Md Abdullah Babu, "Impact of Financial Performance on Green Banking Disclosure: Evidence from the Listed Banking Companies in Bangladesh," Universal Journal of Accounting and Finance, Vol. 10, No. 2, pp. 450 - 456, 2022. DOI: 10.13189/ujaf.2022.100209.

(b): Md. Kazimul Hoque, Mofijul Hoq Masum, Md Abdullah Babu (2022). Impact of Financial Performance on Green Banking Disclosure: Evidence from the Listed Banking Companies in Bangladesh. Universal Journal of Accounting and Finance, 10(2), 450 - 456. DOI: 10.13189/ujaf.2022.100209.

Copyright $\bigcirc 2022$ by authors, all rights reserved. Authors agree that this article remains permanently open access under the terms of the Creative Commons Attribution License 4.0 International License

\begin{abstract}
This paper examines the impact of green banking disclosures on the quality of financial performance over thirty listed banks of the Dhaka Stock Exchange. Time-series data through the year 2014 to 2017 have been scrutinized, out of which we have selected 70 effective samples because of the availability of the green banking disclosures. Multivariate analysis has been conducted where the spending on green banking is used as a dependent variable, the proxy variables of green banking disclosures. As the independent variable of financial performance, we have used three dimensions: profitability, liquidity, and solvency. The ROA, LR, and DAR have been used as proxy variables simultaneously. We found that green banking disclosures and ROA have a considerable positive relationship. In contrast, the other two financial performance variables, LR and DAR, have no statistically significant relationship with green banking spending. The study's findings will encourage the highly profitable listed banks to invest more in greening their activities, ultimately leading to sustainable development in this sector.
\end{abstract}

Keywords Green Banking Disclosures, Financial Performance, Dhaka Stock Exchange

\section{Introduction}

Global warming has gained much attention recently and is regarded as a phenomenon common to almost all countries. This issue is mostly caused by irresponsible environmental treatment and reckless global industrial competition [49]. Moreover, GHG emissions are blamed in many nations for altering natural ecosystems and creating severe repercussions [9], a global response is required [9]. In this regard, significant progress has been made in recent years in terms of policy development and execution to focus on firms' environmental responsibility for GHG emissions, regardless of industry or country [2, 12, 47]. Regulators in developing economies like China, Brazil, India, and Bangladesh, for example, have reacted to the threat. The Brazilian central bank adopted new regulations in April 2014, mandating banks to employ environmental and social risk strategies starting in 2015. Since the 2008 Global Financial Crisis (GFC), banking authorities and policymakers have understood that the banking industry's long-term success is dependent not only on the smooth operation of financial systems but also on the effective management of environmental hazards $[31,50]$. As a result, it is plausible to conclude that commercial banks can play a key role in developing "Green Banking Practices" to reduce environmental hazards. The Bangladesh Bank, the country's banking regulator, issued a series of initiatives known as the green banking guidelines in 2011, directing all commercial banks to adopt and implement this strategy in their daily operations [4]. In response, several literary works were carried out by authors, determining the status of 
implementation of green banking guidelines. Lalon [29] studied green banking policy guidelines and provided an overview of adoption by different banks. Masukujjaman \& Aktar [30] studied the current status of implementation of green banking policy and ranked the top ten banks in their literary work. Green banking is a recent worldwide developing concept, and there is a huge demand for further exploration regarding green banking practices [42] However, there is a lack of literary work on the relationship between financial performance and green banking disclosures in Bangladesh. In this article, we tried to fill that gap.

Green banking disclosure and financial performance are very meticulously related [5]. Environmental liability has become a major issue in today's society, with many stakeholders expecting it $[13,16,27,43]$. Firms that do well in the environment can save money on operations, enhance resource access, and reduce personnel turnover [7]. Furthermore, firms with acceptable environmental performance can benefit from rising demand for environmentally friendly goods and services, opening new market prospects [7, 36]. According to McKendall et al. [37] and Kock and Santaló [28], successful firms based on their return on assets (ROA) have stronger environmental policies since they are more prone to bear high environmental compliance costs. Clarkson et al. [14] discovered a relationship between debt levels and environmental disclosures, meaning that enterprises with greater debt performed better in the environment. Leverage is calculated by dividing total debt by total assets. Roberts [45] and Cormier and Magnan [15] indicate that minimal systemic risk boosts a firm's ability to pursue social responsibility initiatives due to more consistent economic performance. As a result, we've decided on return on asset, debt-to-asset ratio, and liquidity-to-asset ratio as green banking spending metrics.

The study's objective is to assess the impact of green banking disclosures on the quality of financial performance. We have considered the selected samples' profitability, liquidity, and solvency to measure the financial performance. Moreover, to measure the green banking disclosures, we have used the spending on green banking scaled by the total expenses of the selected sample. After the successful completion of the study, the banking industry will get a clear picture of the impact of green banking disclosures on the degree of profitability, liquidity, and solvency. The study's findings will provide a cornerstone for corporate people to invest more in greening their activities. The relevant literature is explained in the latter part of the study, provided the hypothesis investigated in the study is true. The study's methodology is explained in the third section of the paper. The study's fourth component includes an analysis and discussion of the findings, with the final piece focusing on green banking spending and financial success.

\section{Materials and Methods}

\subsection{Literature Review and Hypothesis Development}

\subsubsection{Return on Asset and Green Banking Spending}

The adoption of eco-friendly practices and reducing carbon footprints related to banking operations are referred to as "green banking." It is an attempt not to harm the environment through banking activities. In 2011, the Bangladesh Bank, Central Bank of Bangladesh, designed a framework for green banking policy and strategy, known as the green banking guidelines, to safeguard the environment and guarantee that banking practices are sustainable [3]. These guidelines will be implemented in three phases with specific deadlines. Phase -2 of the Green Banking Policy and Strategy framework [3] requires listed banks to make disclosures to the activities related to green banking. The promotion of environmentally friendly practices and reducing carbon footprints related to banking activities is referred to as green banking. It is an endeavor to ensure that banking activities do not hurt the environment. Green Banking Policy and Strategy Framework, often known as the green banking guidelines, was developed by the Bangladesh Bank, Central Bank of Bangladesh, in 2011 to safeguard the environment and promote sustainable banking operations [3]. These rules will be implemented in three stages, each with its deadlines. Phase 2 of the Green Banking Policy and Strategy Framework [3] mandates that listed banks disclose their green banking efforts. Financial performance refers to a company's ability to manage assets and make profits. [21, 32, 34]. The term is simply a general measure of the overall health of an organization where the performance of an organization over a period of time and the position at a particular date is measured. Different measures are used to assess financial performance, including a measure for profitability, a measure for liquidity, and a measure for solvency. The return on assets assesses profitability, return on equity, and operating profit margin, and it determines how profitable a company can be with its resources [33, 36, 39]. On the other hand, liquidity refers to a company's ability to pay its short-term commitments when they are due, as measured by current ratios. Solvency, which is also a measure of financial performance, assesses a company's ability to meet all of its financial commitments if all of its assets are sold, as well as its ability to continue operating in a viable manner even in the face of financial difficulties [1, 39].

H1: Return on Asset significantly influences the green banking spending 


\subsubsection{Debt Asset Ratio and the Green Banking Spending}

Several studies have been carried out to determine whether environmental regulations or environmental performance impact a company's financial performance. Porter [40] claimed that the benefits of environmental management outweigh the expenses and stricter administrative requirements that will lead to innovation in his famous "win-win" argument. Following that, Porter \& Linde [41] elaborated on the idea, claiming that environmental restrictions may lead to inventions that would benefit and balance the cost of complying with environmental regulations. As an interpretation for relating environmental and company performance, Mark D. Hanna [23] produced a conceptual study that indicated increased customer expectations for "environmentally friendly" goods and services. They also debated the reduction of waste, such as drainage and rubbish, to save money. Many of these studies lack empirical evidence of a link between environmental performance disclosures and company performance. Several authors have investigated the relationship between environmental performance and a company's bottom line. Freedman and Jaggi [20] used the percentage change in three pollutant measures and four accounting ratios as empirical proxies to examine the long-term link between environmental and economic performance. Ullmann [48] also provides a descriptive analysis of previous social-responsibility studies, finding mixed empirical results for pair-wise associations between economic performance and environmental performance, environmental disclosure and environmental performance, and economic performance and environmental disclosure.

On the other hand, Jaffe et al. [26] indicated that this positive association between environmental and financial performance coexists with other points of view, claiming that improving an enterprise's environmental effect leads to a decrease in profitability. It's also been stated that complying with environmental standards costs a lot of money, decreasing a company's ability to compete. A significant link was discovered between environmental proactivity and firm performance [38]. However, an empirical assessment of the impact of environmental performance on financial success in the Indian banking sector Rajput et al. [44] found no link between environmental and financial performance.

H2: Debt Asset Ratio significantly influences green banking spending.

\subsubsection{Liquidity and the Green Banking Spending}

Liquidity refers to a bank's ability to meet debt obligations when they become due without incurring unacceptable losses [6]. The liquidity ratio is concerned with how bank runs occurred during the financial crisis [17]. The European Central Bank explains that a bank's performance is defined as its ability to generate sustainable profitability, which is necessary for banks to continue operating and for stockholders to receive fair returns; and it is also necessary for supervisors, as it guarantees more resilient solvency ratios, even in a riskier business environment. Studies have found a link between environmental sustainability and financial success, such as a bank's liquidity or solvency $[22,24]$. There are a few instances where implementing a green management system has resulted in cost savings, improved organizational solvency, increased bond value, and so on [25]. Green banking, on the other hand, raises the organization's running costs because it requires specialized personnel, skills, and knowledge because of the consumers it serves. Mortgage officers, for example, must have additional knowledge and training in working with green banking and consumers [10]. We have assumed the following hypothesis based on the above discussion:

\section{H3: Liquidity Ratio significantly influences the green banking spending}

\subsection{Sample Design}

The banking sector of Bangladesh is selected as a sample of precisely 30 listed banks under the Dhaka Stock Exchange. The last four years' data have been collected where there are 120 samples available from which 70 effective samples are being chosen. Others are not taken because of the unavailability of green banking spending. The years before 2012 were not taken because of starting the green banking phase by Bangladesh Bank launched in 2012. The sampling technique is systematic random sampling.

\subsection{Variable Design}

The proportion of Green Banking Spending (GBS) is selected as a dependent variable where Green Banking Spending (GBS) is scaled by total expenditure. The GBS has been selected as a proxy of green banking disclosure. The financial performance of the company is the independent variable where Return on Asset (ROA), Liquidity Ratio (LR), and Debt to Asset Ratio (DAR) are selected as a proxy of financial performance. Here Return on Asset (ROA) is Net Profit (before any extraordinary expense) scaled by Total Assets (except preliminary cost). ROA has been chosen because it best represents the profitability of the company. Liquidity ratio (LR) is Current Assets (i.e., Cash in treasury banks and treasury bank balances accounts with other financial institutions, Lending to other banks and financial institutions, Net Investments, and Net Advance) divided by Current Liabilities (i.e., Bills payable, Borrowings, Deposits, and other accounts)) which represent liquidity condition of a business and more liquidity leads to more investment on GBP. Debt to Asset Ratio (DAR) is where Total Liabilities (summation of Current liability and Long term liabilities) are scaled by Total Assets (except preliminary cost), the representation of the solvency of the company. 
Our research model is stated below:

$$
\mathrm{GBP}=\alpha+\beta_{1} \mathrm{ROA}+\beta_{2} \mathrm{LR}+\beta_{3} \mathrm{DAR}-\mu
$$

Where,

ROA $=$ Return on Asset

LR = Liquidity Ratio

DAR $=$ Debt to Asset Ratio

Table 1. Measurement of variables

\begin{tabular}{|l|l|}
\hline \multicolumn{2}{|c|}{ Independent Variables } \\
\hline $\begin{array}{l}\text { Return on } \\
\text { Asset }\end{array}$ & $\begin{array}{l}\text { Here it is calculated by dividing net income by } \\
\text { average total assets [(Opening Assets + Closing } \\
\text { Assets)/2] }\end{array}$ \\
\hline $\begin{array}{l}\text { Liquidity } \\
\text { Ratio }\end{array}$ & $\begin{array}{l}\text { It is measured by the current ratio that is current } \\
\text { asset scaled by current liability }\end{array}$ \\
\hline $\begin{array}{l}\text { Debt to } \\
\text { Asset Ratio }\end{array}$ & $\begin{array}{l}\text { It is calculated by dividing the total debt by total } \\
\text { assets. }\end{array}$ \\
\hline \multicolumn{1}{|c|}{ Dependent Variables } \\
\hline $\begin{array}{l}\text { Green } \\
\text { Banking } \\
\text { Spending }\end{array}$ & $\begin{array}{l}\text { The total expenses of the bank scale the total } \\
\text { amount of green banking expenses reported in the } \\
\text { income statement. }\end{array}$ \\
\hline
\end{tabular}

\section{Results and Discussion}

\subsection{Descriptive Analysis}

Table 2. Descriptive Statistics

\begin{tabular}{|c|c|c|c|}
\hline & Mean & Std. Deviation & N \\
\hline GBP & .11 & .05 & 70 \\
\hline ROA & .41 & .25 & 70 \\
\hline L_R & 1.30 & 1.08 & 70 \\
\hline DE_R & .53 & .26 & 70 \\
\hline
\end{tabular}

\subsection{Correlation Analysis}

We have found a moderate positive correlation $(0.437)$ between green banking spending and return on assets from the correlation coefficient. It represents that GBS is strongly tied with the banking sector's profitability. In practice, the more profitable bank will spend more on green banking. The second highest correlation coefficient $(-0.399)$ has been found between the debt-equity ratio and green banking spending but in an inverse direction. It represents that the more the bank is solvent, the less likely to spend on green banking. This result represents the phenomena of the least developing country as more vigilance of the external capital in the capital structure, and the less the companies spend on green banking due to the payment of the external cost of capital. A weak positive relationship has been observed for all other dependent and independent variable combinations.

Table 3. Correlation coefficient

\begin{tabular}{|c|c|c|c|c|c|}
\hline & & GBP & ROA & L_R & DE_R \\
\hline $\begin{array}{c}\text { Pearson } \\
\text { Correlation }\end{array}$ & GBP & 1.000 & & & \\
\hline & ROA & .437 & 1.000 & & \\
\hline & L_R & .187 & .165 & 1.000 & \\
\hline & DE_R & .202 & .313 & -.399 & 1.000 \\
\hline
\end{tabular}

\subsection{Goodness of Fit of the Proposed Model}

From the model summary table, the adjusted R square value is 0.19 , which indicates the independent variables, namely, Return on Asset (ROA), Liquidity Ratio (LR), and Debt to Asset Ratio (DAR), explain 19\% variations of the dependent variable, Green Banking Spending (GBS). From the ANOVA table, we can conclude that the value of the adjusted $\mathrm{R}$ square can never be less than zero, which is statistically significant at $\mathrm{P}<0.001$, representing the goodness of the fit of the proposed model.

Table 4. Model Summary

\begin{tabular}{|c|c|c|c|c|c|}
\hline Model & R & R Square & Adjusted R Square & $\begin{array}{c}\text { Std. Error of the } \\
\text { Estimate }\end{array}$ & $\begin{array}{c}\text { Level of } \\
\text { Significance }\end{array}$ \\
\hline GBP & .474 & .225 & .190 & .0422956 & 0.000 \\
\hline
\end{tabular}

a Predictors: (Constant), DE_R, ROA, L_R b Dependent Variable: GBP

Table 5. Regression Coefficients

\begin{tabular}{|c|c|c|c|c|c|c|c|}
\hline \multirow[t]{2}{*}{ Variables } & \multicolumn{2}{|c|}{ Unstandardized Coefficients } & \multirow{2}{*}{$\begin{array}{c}\text { Standardized } \\
\text { Coefficients }\end{array}$} & \multirow[t]{2}{*}{$\mathrm{t}$} & \multirow[t]{2}{*}{ Sig. } & \multicolumn{2}{|c|}{ Collinearity Statistics } \\
\hline & $\mathrm{B}$ & Std. Error & & & & Tolerance & VIF \\
\hline (Constant) & .052 & .016 & & 3.182 & .002 & & \\
\hline ROA & .066 & .023 & .351 & 2.899 & .005 & .802 & 1.246 \\
\hline L_R & .009 & .005 & .198 & 1.580 & .119 & .748 & 1.337 \\
\hline DE_R & .032 & .024 & .172 & 1.319 & .192 & .694 & 1.442 \\
\hline
\end{tabular}

a Dependent Variable: GBP 


\subsection{Regression and Hypothesis Analysis}

From the regression coefficient table, is found that there are no multicollinearity problems on the independent variables as the tolerance value of each of the independent variables is more variables0 [46]. In contrast, the VIF value of all the independent variables is less than 10 . The regression coefficient table found the highest beta value (0.351) for ROA, which is statistically significant at 0.01 . This implies that the bank has the highest profitability spending more on green banking and discloses more information on green banking activities. Thus our first hypothesis, Return on Asset (ROA), significantly influences the Green Banking Spending (GBS), has been accepted based on the sample information. McKendall et al. [37] and Kock and Santaló [28] also found that successful firms based on their return on assets (ROA) have stronger environmental policies since they are more prone to bear high environmental compliance costs. For the context of the emerging economy - Bangladesh without having sufficient financial backings, it is quite impossible to spend more on greening their activities. Thus the findings of the study bring a fruitful conclusion in the context of Bangladesh. It will encourage the listed profitable banking companies (most of the listed commercial banks of Bangladesh are profitable) to invest more in green banking. On the other hand, the other two hypotheses $\mathrm{H} 2$ and $\mathrm{H} 3$, are rejected, although there exists positive relation, which is statistically insignificant as p $>0.1$ in each of the cases. Our second hypothesis assuming that Debt Asset Ratio significantly influences green banking spending was rejected as no significant relationship can be found between the debt asset ratio and green banking spending. This finding is also consistent with the findings of Rajput et al. [44] who found no significant relations between environmental and financial performance-based Indian banking sector.

\section{Conclusions}

As sustainability is one of the crucial issues in the new business world [18, 19, 24, 35], most banks are moving for green banking practices and spend a significant amount of resources. From the literature on green banking, it was found that highly banking institutions tend to disclose more green banking information in their annual reports $[26,38]$ in the context of an emerging economy. Although previous studies showed inconsistent findings [28]. This study added value to the literature on green banking by explaining the relationship between financial performance and green banking disclosures in the context of an emerging economy, Bangladesh. This study measures the success of green banking spending in terms of financial performance. We have used three proxy variables of financial performance: return on assets, liquidity ratio, and the debt-asset ratio of the selected Bangladeshi private bank. It is found that there is a direct connection of green banking spending with return on assets where the other proxy variables have an inverse relation with green banking spending. This finding is consistent with the findings of prior studies $[8,11]$. The study's findings encourage more private banks to practice green banking in their organization, as spending on green banking will better financial performance. The study's overall findings will help the banks think about their green banking spending, ensuring environmental sustainability, and the organization's profitability. In this research, it is found that the study has certain limitations; firstly, the study is conducted based on secondary data, which is the organization's annual report, while the primary data may provide an in-depth understanding of the green banking scenario in the developing countries like Bangladesh. Secondly, only a few financial performance indicators are used in this study, providing inflated results.

In contrast, the other financial indicators like marketbased and mixed indicators can provide more robustness of the findings. Thirdly, it only considered the crosssectional data rather than the panel-data study. Moreover, the study is based on quantitative analysis, where the qualitative study was not considered. Several broad areas of studies can explore the following emerging issues factors influencing the green banking disclosures in emerging economies, the impact of corporate governance on green banking disclosures in developing economies, and the impact of green banking disclosures on the sustainable growth of the banking sectors.

\section{Acknowledgements}

We are grateful to the United International University, Bangladesh to provide us the fund for conducting this empirical study.

\section{REFERENCE}

[1] Ahmed, H., Uddin, M., \& Masum, M. H. The Inclination of Corporate Voluntary Environmental Disclosure in Bangladesh: Effect of Size, Industry, and Operating Performance. Academy of Strategic Management Journal, vol. 20 no. 2, pp. 1-6, 2021. https://www.abacademies.org/articles/the-inclination-ofcorporate-voluntary-environmental-disclosure-inbangladesh-effect-of-size-industry-and-operatingperformance-10424.html

[2] Babu, M. A., \& Masum, M. H, Crucial Factors for the Implementation of Activity-Based Costing System: A Comprehensive Study of Bangladesh. ABC Research Alert, vol. 7 no. 1, Bangladesh-Bangladesh, 2019. DOI: https://doi.org/10.18034/abcra.v7i1.246

[3] Bank, B. Policy guidelines for green banking. BRPD Circular, vol. 2, 2011 
[4] Bank, B. Reporting green banking activities under Phase II, 2017.

[5] Barbera, A. J., \& McConnell, V. D. The impact of environmental regulations on industry productivity: direct and indirect effects. Journal of environmental economics and management, vol. 18, no.1, pp. 50-65, 1990. DOI: https://doi.org/10.1007/BF01206060

[6] BASEL, C. Principles for sound liquidity risk management and supervision. Basel Committee on Banking Supervision, 2008.

[7] Berrone, P., \& Gomez-Mejia, L. R.Environmental performance and executive compensation: An integrated agency-institutional perspective. Academy of Management Journal, vol. 52, no.1, pp. 103-126, 2009. DOI: https://doi.org/10.5465/AMJ.2009.36461950

[8] Bhardwaj, B. R., \& Malhotra, A. Green banking strategies: sustainability through corporate entrepreneurship. Greener Journal of Business and Management Studies, vol. 3, no. 4, pp. 180-193, 2013. DOI:DOI:10.15580/GJBMS.2013.4.12 2412343

[9] Bhuiyan, M. N. U., \& Masum, M. H. Balanced scorecard: A multi-stream performance measurement tool for public sector corporations in Bangladesh. The Cost and Management, vol. 38, no. 5, pp. 19-25, 2010.

[10] Biswas, N. Sustainable green banking approach: The need of the hour. Business Spectrum, vol. 1, no. 1, pp. 32-38, 2011.

http://admin.iaasouthbengalbranch.org/journal/1_Article5. pdf

[11] Bose, S., Bhattacharyya, A., \& Islam, S. Dynamics of firmlevel financial inclusion: Empirical evidence from an emerging economy. Journal of Banking and Finance Law and Practice, vol. 27 no.1, pp. 47-68, 2016. https://papers.ssrn.com/sol3/papers.cfm?abstract_id=2782 479

[12] Bowman, M. The role of the banking industry in facilitating climate change mitigation and the transition to a lowcarbon global economy. Environment and Planning Law Journal, vol. 27, pp. 448, 2010. http://vuir.vu.edu.au/id/eprint/6925

[13] Buysse, K., \& Verbeke, A. Proactive environmental strategies: A stakeholder management perspective. Strategic management journal, vol. 24, no. 5, pp. 453-470, 2003. DOI: $10.1002 / \mathrm{smj} .299$

[14] Clarkson, P. M., Li, Y., Richardson, G. D., \& Vasvari, F. P. (2008). Revisiting the relation between environmental performance and environmental disclosure: An empirical analysis. Accounting, organizations and society, vol. 33 no. 4-5, pp. 303-327, 2008. DOI: https://doi.org/10.1016/j.aos.2007.05.003

[15] Cormier, D., \& Magnan, M. The impact of the web on information and communication modes: the case of corporate environmental disclosure. International Journal of Technology Management, vol. 27, no. 4, pp. 393-416, 2004. DOI:10.1504/IJTM.2004.004278

[16] Delmas, M. A., \& Toffel, M. W. (2008). Organizational responses to environmental demands: Opening the black box. Strategic Management Journal, vol. 29, no, 10, pp. 1027-1055, 2008. DOI: https://doi.org/10.1002/smj.701
[17] Diamond, D. W., \& Dybvig, P. H. Bank runs, deposit insurance, and liquidity. Journal of political economy, vol. 91, no. 3, pp. 401-419, 1983. https://www.jstor.org/stable/1837095

[18] Engardio, P., Capell, K., Carey, J., \& Hall, K. Beyond the green corporation. Business Week, vol. 29, pp. 50-64, 2007. https://www.bloomberg.com/news/articles/2007-0128/beyond-the-green-corporation

[19] Esty, D. C., \& Winston, A. Green to gold: How smart companies use environmental strategy to innovate, create value, and build competitive advantage: John Wiley \& Sons, 2009, pp. 105-122

[20] Freedman, M., \& Jaggi, B. An investigation of the long-run relationship between pollution performance and economic performance: the case of pulp and paper firms. Critical Perspectives on Accounting, vol. 3, no. 4, pp. 315-336, 1992. DOI: https://doi.org/10.1016/1045-2354(92)90024-L

[21] Greenwood, J., \& Jovanovic, B. Financial development, growth, and the distribution of income. Journal of Political Economy, Vol. 98, no. 5, Part 1, pp. 1076-1107, 1990. https://www.jstor.org/stable/2937625

[22] Hamilton, J. T. Pollution as news: Media and stock market reactions to the toxics release inventory data. Journal of environmental economics and management, vol. 28, no.1, pp. 98-113, 2017. DOI: https://doi.org/10.1006/jeem.1995. 1007

[23] Hanna, M. D., \& Rocky Newman, W. Operations and environment: an expanded focus for TQM. International Journal of Quality \& Reliability Management, vol. 12, no. 5, pp. 38-53, 1995. DOI: 10.12691/jbms-2-6-1

[24] Hart, S. L. Capitalism at the crossroads: The unlimited business opportunities in solving the world's most difficult problems: Pearson Education, 2005.

[25] Heim, G., \& Zenklusen, O. Sustainable finance: Strategy options for development financing institutions. Eco: Fact, Stampfenbachstrass, Zurich, 2005.

[26] Jaffe, A. B., Peterson, S. R., Portney, P. R., \& Stavins, R. N. Environmental regulation and the competitiveness of US manufacturing: what does the evidence tell us?. Journal of Economic Literature, vol. 33, no. 1, pp. 132-163, 1995. https://www.jstor.org/stable/2728912

[27] Kassinis, G., \& Vafeas, N. Stakeholder pressures and environmental performance. Academy of Management Journal, vol. 49, no. 1, pp. 145-159, 2006. https://doi.org/10.2307/20159751

[28] Kock, C. J., \& Santaló, J. Are shareholders environmental laggards? Corporate governance and environmental firm performance. Corporate Governance and Environmental Firm Performance (January 19, 2005). Instituto de Empresa Business School Working Paper No. WP05-05, 2005. https://ideas.repec.org/p/emp/wpaper/wp05-05.html

[29] Lalon, R. M. Green banking: Going green. International Journal of Economics, finance and management sciences, vol. 3, no. 1, pp34-42, 2015 DOI: 10.11648/j.ijefm.20150301.15

[30] Masukujjaman, M., \& Akter, S. Green banking in Bangladesh: A commitment towards the global initiatives, 2013. DOI:10.3329/jbt.v8i1-2.18284 
[31] Mandelson, P. (2008). In defence of globalisation. The Guardian, 3(10), 2008. https://www.theguardian.com/com mentisfree/2008/oct/03/globalisation.globaleconomy

[32] Masum, M. H., Hassan, N., \& Jahan, T. Corporate climate change reporting: Evidence from Bangladesh. Accounting and Management Information Systems, vol. 18, no. 3, pp. 399-416, 2019. https://ideas.repec.org/a/ami/journl/v18y20 19i3p399-416.html

[33] Masum, M. H., \& Khan, M. M. Impacts of Board Characteristics on Corporate Performance: Evidence from Bangladeshi Listed Companies. International Business and Accounting Research Journal, vol. 3, no. 1, pp. 47-57, 2019. DOI: http://dx.doi.org/10.15294/ibarj.v3i1.54

[34] Masum, M. H., Latiff, A. R. A., \& Osman, M. N. H. Determinants of corporate voluntary disclosure in a transition economy. Problems and Perspectives in Management, vol. 18, no. 4, pp. 130, 2021. DOI: http://dx.doi.org/10.21511/ppm.18(4).2020.12

[35] Masum, M. H., Latiff, A. R. A., \& Osman, M. N. H. Voluntary Reporting, Sustainable Reporting and Transition Economy. International Business and Accounting Research Journal, vol. 4, no. 2, pp. 81-88, 2020. DOI: http://dx.doi.org/10.35474/ibarj.v4i2.138

[36] Masum, M. H., Latiff, A. R. A., \& Osman, M. N. H. Ownership structure and corporate voluntary disclosures in transition economy. The Journal of Asian Finance, Economics, and Business, vol. 7, no. 10, pp. 601-611, 2020. DOI: https://doi.org/10.13106/jafeb.2020.vol7.no10. 601

[37] McKendall, M. A., Sinchez, C. M., \& Sicilian, P. Corporate governance and corporate illegality: The effects of board structure on environmental violations. In Proceedings of the International Association for Business and Society, vol. 7, pp. 167-178, 1996. https://core.ac.uk/download/pdf/323 386353.pdf

[38] Molina-Azorín, J. F., Claver-Cortés, E., Pereira-Moliner, J., \& Tarí, J. J. Environmental practices and firm performance: an empirical analysis in the Spanish hotel industry. Journal of Cleaner Production, vol. 17, no. 5, pp. 516-524, 2009. DOI : 10.1016/j.jclepro.2008.09.001

[39] Oltmans, A. W., Klinefelter, D. A., \& Frey, T. L. AFRA: agricultural financial reporting and analysis. Century Communications, $1992 . \quad$ https://agris.fao.org/agrissearch/search.do?recordID=US19950073920

[40] Porter, M. E. (1991). America's Green Strategy, 264 Sci. Am, vol. 68, pp. 168, 1991. DOI: http://dx.doi.org/10.1038/ scientificamerican0491-168
[41] Porter, M., \& LINDE, V. Green and Competitive, Harvard Business Review. Sep/Oct, 1995. https://hbr.org/1995/09/gr een-and-competitive-ending-the-stalemate

[42] Procopio G., Trotta A., Strano E., Iannuzzi A.P. (2020) Green Banking in Italy: Current and Future Challenges. In: La Torre M., Chiappini H. (eds) Contemporary Issues in Sustainable Finance. Palgrave Studies in Impact Finance. Palgrave Macmillan, Cham. https://doi.org/10.1007/978-3030-40248-8_9

[43] Rahman, M. M., \& Masum, M. H. Extent of Corporate Social Responsibility Disclosure: Evidence from Bangladesh. The Journal of Asian Finance, Economics and Business, vol. 8, no. 4, pp. 563-570, 2021. DOI: https://doi.org/10.13106/jafeb.2021.vol8.no4.0563

[44] Rajput, N., Arora, M. S., \& Khanna, M. A. An empirical study of impact of environmental performance on financial performance in Indian banking sector. International Journal of Business and Management Invention, vol. 2, No. 9, pp.19-24, 2013. https://www.ijbmi.org/papers/Vol(2)9/ Version-1/D0291019024.pdf

[45] Roberts, R. W. Determinants of corporate social responsibility disclosure: An application of stakeholder theory. Accounting, organizations and society, vol. 17, no. 6, pp. 595-612, 1992. DOI: https://doi.org/10.1016/03613682(92)90015-K

[46] Tabachnick, B. G., \& Fidell, L. S. SAS for windows workbook for Tabachnick and Fidell using multivariate statistics. Allyn and Bacon, 2001.

[47] Tauringana, V., \& Chithambo, L. The effect of DEFRA guidance on greenhouse gas disclosure. The British Accounting Review, vol. 47, no. 4, pp. 425-444, 2015. DOI: https://doi.org/10.1016/j.bar.2014.07.002

[48] Ullmann, A. A. Data in search of a theory: A critical examination of the relationships among social performance, social disclosure, and economic performance of US firms. Academy of management review, vol. 10, no. 3, pp. 540557, 1985. https://journals.aom.org/doi/abs/10.5465/amr.1 985.4278989

[49] UNEP Finance Initiative. Green Financial Products and Services-Current Trends and Future Opportunities in North America. A Report of the North American Task Force (NATF) of the United Nations Environment Programme Finance Initiative, 2007.

[50] Welcoming a new generation of green financial policy innovation.(2014) Retrieved December 22, 2019 from http://www.theguardian.com/sustainable-business/greenfinancial-policy-new-generation 